\title{
THE ANALYSIS OF CUSTOMERS' SATISFACTION TOWARDS COMMUTER LINE TRAIN SERVICE A CASE STUDY AT BEKASI STATION, BEKASI - JAKARTA KOTA ROUTE
}

\author{
Johannes Partogi ${ }^{1}$, M Ivan Vicahya Dewangga ${ }^{2}$, Paul S Hutauruk ${ }^{3}$ \\ 1. STMT Trisakti, 2. STMT Trisakti, 3. STMT Trisakti \\ $\bowtie$ corresponding author: johannespartogi007@gmail.com
}

\begin{abstract}
This research is aimed to analyse and determine the level of customers' satisfactions towards Commuter line service. This is a descriptive quantitative research. The data collection was done by literature study, field study, observation and questionnaires distribution. The data came from questionnaires which were given to 99 respondents who use commuter line service, especially Bekasi- Jakarta Kota route. For the data analysis, the important performance analysis is used and there are 25 items of questions included. All types of questions were given to respondents. There were some questions considered as very important to be increased due to the unsatisfactory level of service according to the respondents, such as, temperature of the carriages, the punctuality of departure schedule, the readiness and fast response skills of commuter line officers in response to requests or complaints from users of commuter line services.
\end{abstract}

Keyword: Commuter Line, Importance Performance Analysis, Customer Sasisfaction

\section{Introduction}

The high necessity level of the society for the mass transportation in Indonesia is very important. It has become viral together with the increase of population number in this city and customer need about mass transportation, especially in Jabodetabek. understanding the characteristics of individual customer is important for being able to fulfill the customer demand on a marketed product or service (Simarmata, 2017). So Mass transportation becomes very important in fulfilling customers or passengers need for transportation mode that can carry lot of passengers.

Bekasi is a city with a large number of residents who work in other cities like Jakarta. This is one of the reasons for the highly needed of mass transportation for its society. One of transportation mode that relatively cheap with big capacity to support the activitiy of society is train (Thamrin, 2016) and Train is a good alternative that people who live in Bekasi use as it is effective and efficient and can carry passengers in a mass number (WIBOWO, 2013). PT.Kereta Api Commuter Jabodetabek (PT KCJ) mainly focus on serving people who need transportation. Those are who live in 
remote area and commute daily to other city like jakarta and the surroundings (JABODETABEK) (Maesarini, 2013)

Commuter line becomes main mode of Bekasi's residents in daily commuting. However, since more and more people use commuter line, it is very crowded now. The condition raises many complaints from the customers of commuter line that there is not enough train to carry all passengers, it causes less safety and comfortability whether in station and inside the train (Maesarini, 2013). Employee or company can only behave totally in a customer-orientation way whenever all the dimensions are present: having motivation, competence, and possibility to treat customers in accordance with their need (Simarmata, 2017). And Various policy have been released to minimilize those transportation problems, but it will not effectively work if the management does not fixed (Kadarisman, 2016)

Based on the above background, the writers are interested in discussing about passengers' satisfaction level of commuter line service quality. In this paper the writers used descriptive quantitative method with Importance Performance Analysis ( IPA ) to reach conclusion through questionnaire.

\section{Method}

This is a quantitative descriptive research which is aimed to find accurate and precise facts, and a systematic picture. This research was conducted at PT Kereta Commuter Line Jabodetabek at Bekasi station especially for Bekasi - Jakarta Kota route. This research took one month starting from October to November 2017. Due to the time limit, the writers only took 99 samples of passengers of commuter line train from Bekasi to Jakarta Kota. Questionnaire is used as data collection method.

Importance Performance Analysis (IPA) was used to analyse the data. Descriptive quantitative method is used to analyse research data and to answer problems' formulation about how far is the level of customers' satisfaction towards the company's performance. This analysis is based on 
the results of research of consumer expectations and performance research results or appearance. It will produce a calculation of the level of fit between expectations and implementation. The level of conformity is the result of comparison of performance scores with the expectation scores. This level of conformity will determine the priority order of increasing the factors that affect customer satisfaction (Supranto, 2011)

There are two variabels represented in this study. Those variables are represented by letter $\mathrm{X}$ and $\mathrm{Y}$. $\mathrm{X}$ is company performance level while $\mathrm{Y}$ is customers' interest level. To measure the level of conformity the writers use this formula (J. Supranto, 2011: 241):

$$
T k i=\frac{X_{i}}{Y_{i}} \times 100 \%
$$

Remarks: $\quad$ Tki $=$ sustainability respondents

$$
\begin{aligned}
& \mathrm{Xi}=\text { Score assessment performance (performance) } \\
& \mathrm{Yi}=\text { Score assessment interests customer }
\end{aligned}
$$

Next axis horizontal (X) will be filled by score level implementation.

While axis vertical (Y) will be filled by level of interests.

The simplification formula to find average balance level

for every dimension to find the average customers' satisfaction with:

$$
R T k i=\frac{\sum D T k i}{n}
$$

Notes :

$\mathrm{RTki}=$ average balance level

$\sum D T k i=$ The average score of the balance level of each dimension $\mathrm{n}=$ Number of question items

This analysis is based on the results of research of expectations level and results of performance level that will produce calculation of the level of satisfaction between the level of expectations and implementation. The level of conformity is the result of comparison of performance scores with the expectation score. The higher level of conformity creates greater quality of service. 
The data analysis is equipped by Cartesian analysis diagram which was aimed to determine the quality level of service on Commuter line. This line of analysis was used to determine what steps would be taken to improve the Commuter line service. This step was to describe the variables into the Cartesian diagram based on performance appraisal (performance) of the commuter line system and the expectation assessment. As $\mathrm{X}$ axis is Performance (performance) of commuter line system and $\mathrm{Y}$ axis is Customer expectation can be seen in table 1 .

Information :

1. Quadrant A shows the factors or attributes that are considered to affect customer satisfaction, including the elements of services that are considered very important, but the management has not implemented according to customer desires. So disappointing / dissatisfied.

2. Quadrant B shows the element of service that has been successfully executed by the company, it must be maintained. Considered very important and very satisfying.

3. Quadrant $\mathrm{C}$ shows several factors that are less important to the customer, the implementation by the company is not satisfactory or ordinary. Considered as less important and less satisfactory.

4. Quadrant D shows factors that affect customers less important, but excessive implementation. Considered as less important but much satisfactory.

\section{Discussion and Result}

As one example of the calculation on one of the attribute statements in the tangibles dimension attributes questioned the cleanliness in the train (Xi) $=3.77$ and the expectation score $(\mathrm{Yi})=4.59$, then the level of conformity is as follows:

$$
\mathbf{T} \boldsymbol{k}=\frac{X_{i}}{Y_{i}} \quad \times 100 \%=\frac{3.77}{4.59} \quad \times 100 \%=\mathbf{8 2 . 1 4 \%}
$$


The same formula was used for each attributes in a questionnaire to determine the level of balance; there are 25 attributes which can be seen in Table 1.

Tangibles Dimension

All performance details for attribute question can be seen in table 1 and the calculation used was formula Tki. Based on the details of the data from table 1 can be seen the highest score of performance is attribute question no 1 Cleanliness in train with 3,77 and also the highest score for expectation is attribute question no 1 with 4,59, so we can conclude that the train is clean and the passengers are satisfied with the performance of commuter line.

Based on the results of the data above, analysis can be calculated on the average of the overall suitability tangible dimension of $82.92 \%$. It can be seen by the results of the analysis can be drawn by conclusion that the level of service quality in tangible dimensions not in line with expectations of commuter line passengers because the average level of conformity is about $82.92 \%$, still below $100 \%$.

\section{Reliability Dimension}

Based on the details of the data from table 1, it can be seen that the highest score of performance is attribute question no 12 . Officers know very well about time departure and path train for all routes with 3,56. The highest score of expectation for commuter line passengers is also in the same attribute question no 12 with 4.26. It is assumed that the passengers want the officers know all about time departure and path train correctly.

Based on the results of the data above, it can be calculated that the average of the overall reliability dimension level is $81.76 \%$. From the results of the analysis, the conclusion can be drawn that the level of service quality in the dimensions of reliability has not been in line with expectations of commuter line passengers' line, because the average level of conformity is $81.76 \%$ which is still below $100 \%$.

\section{Responsiveness Dimension}

Based on the details of data from table 1, it can be seen that the highest score of performance in dimension of responsiveness is attribute question no 15, the readiness of officers to take a look and receive complaints 
from passenger with 3,47. The expectation from passangers attribute question no 14,15 and 17 showed similar score which is 4,02 . So that we can conclude that for the responsiveness showed 3 highest score of expectation but only one attribute question fulfilled passengers' satisfaction.

Based on the results of the data above, analysis can be calculated on average of the overall responsiveness dimensions which is $86.05 \%$. From the analysis, it can be concluded that the level of service quality dimensions responsiveness was not in line with the expectations of commuter line passengers because the average level of suitability is $86.05 \%$ which is below $100 \%$.

\section{Assurance Dimension}

Based on the details of data from table 1, we can see the score for attribute question no 18 , ability of officers in running his job is 3,80 . It is a high score for performance of assurance dimension and the highest score for expectation is attribute question no 22, ability of officers in keeping passenger's security whether in train or station with 4,21 .

Based on the results of the data above, analysis can be calculated on average of the overall suitability level of assurance dimensions is $74.55 \%$. The results of the analysis can be drawn by the conclusion that the level of service quality in assurance dimensions not in line with expectations of commuter line passengers and become the worst of all dimensions that exist because the average level of conformity is $74.55 \%$ and the value is still far below $100 \%$.

\section{Empathy Dimension}

Based on the details of data from table 1, it can be seen that the highest score of performance in dimension of responsiveness is attribute question no 25. Commuter line company effort in understanding passenger's need was 3,66 . The highest score of expectation for passenger of commuter line is attributed question no 23. The ability of officer in communicate with customer in understanding language was 4, 20. 
Based on the results of the data above, analysis can be calculated on average of the overall suitability level of empathy dimensions which is 87 , $21 \%$. Cconclusion can be drawn as a result of the analysis that the level of service quality in empathy dimensions was not in line with expectations of commuter line passengers. It has become the worst of all dimensions existed because the average level of conformity was $87,21 \%$ and the value is still far below $100 \%$.

\section{Cartesian Analysis Diagram}

The Cartesius Diagram analysis aims to determine the quality of service on commuter line trains. This analysis can also be used to identify improvement measures through improved service on the commuter line train service line. This step is to describe the variables into the Cartesian diagram based on performance appraisal (performance) of the commuter line and the expectation of the commuter line's passengers. As the $\mathrm{X}$ axis is Performance (performance) commuter line and $\mathrm{Y}$ axis is Customer's expectation. Cartesian diagram is a wake divided into four parts bounded by two lines intersecting perpendicular to the points $(\mathrm{X}, \mathrm{Y})$, by the formula:

$$
\bar{X}=\frac{\sum X i}{\mathrm{~N}} \quad \text { Dan } \quad \bar{Y}=\frac{\sum Y i}{\mathrm{~N}}
$$

From the formula above, average suitability level can be calculated as:

$$
\begin{aligned}
& \bar{X}=\frac{3,77+3,55+3,40+\ldots+3,66}{25}=3,51 \\
& =\bar{Y}=\frac{4,59+4,40+4,27+\ldots+4,14}{25}=4,16
\end{aligned}
$$

From the calculation above, the average value of performance is 3.51 and the average value of expectations is 4.16 . The average number of performance is made as the boundary point of the $\mathrm{X}$-axis quadrant and the expected average value is made as the point of the $\mathrm{Y}$ axis quadrant line divider. It can be drawn from Cartesian diagram which was divided into 4 quadrants :

Quadrant A, as an item with expected value is above 4.16 and its performance value is less than 3.51

Quadrant B, as an item with expected value is above 4.16 and its performance value at more than 3.51 
Quadrant C, as an item with expected value is below 4.16 and its performance value is less than 3.51

While the quadrant $\mathrm{D}$, as an item with expected value below 4.16 and performance value above 3.51. Furthermore, it can also be seen further in drawing cartesius diagram in table 2.

Based on the cartesian diagram illustrated in table 2 all dimensions are already in different quadrants. This can be explained as follows:

\section{Quadrant A}

Items in Quadrant A can be interpreted as these questions have below average performance levels but the expectations of the users of the commuter line train are quite high. Items in quadrant A should be prioritized for improving performance of commuter line train because according to the user the item is very important but its performance is low:

The question item for Quadrant A is :

a) Item no 3: well function of the air conditioner in the car

b) Item no 10: accuracy of departure schedule

PT commuter line must improve their performance of those two items in which the commuter line train users think that the coolant in the carriage is very important. Commuter line must check periodically to keep all air conditioners well functioned and pay more attention to the accuracy of the departure schedule.

\section{Quadrant B}

The items in Quadrant B are question items which greatly affect the commuter line train user's satisfaction, as their performance levels match the expectations of the users to satisfy the commuter line train users.

The question items in quadrant $B$ are:

a) Item no 1: cleanliness inside the train

b) Item no 2: cleanliness inside the station

c) Item no 6: availability of officers guarding the train line crossings 
d) Item no 12: knowledge of the officer for the departure time and railway line of all routes

e) Item no 13: the ability of the facility to provide information on the existence of train or other information

f) Item no 22: the officer's ability to keep passengers safe in train and station

g) Item no 23: the ability of the officer to communicate with customers easily and perceivably.

Thus, PT Kereta commuter line must maintain the seven items above to meet the expectations of the users of the commuter line train service.

\section{Quadrant C}

The question items in Quadrant C are those items which according to the users of the commuter line train are not very important and the performance provided is ordinary or sufficient.

The query items in Quadrant C are:

a) Item no 4: number of officers guarding in the train

b) Item no 8: availability of information officers at the station

c) Item no 7: availability of bench while waiting for train at station

d) Item no 11: train speed to destination station

e) Item no 14: the officer's ability to respond and receive complaints from passengers

f) Item no 15: readiness of officers in responding and accepting passenger complaints

g) Item no 16: readiness of officers in response to requests from passengers

h) Item no 17: the speed of the officer in response to requests from passengers.

i) Item no 19: friendly officers in providing services \& information.

The above data shows that PT commuter line must make up for the performance of officers who provide services for commuter line passengers. Commuter line train is expected to increase the officers' performance by 
giving training. This effort is to improve the readiness performance and speed of response from commuter line train officers.

\section{Quadrant D}

The question items in Quadrant D are those about the service that commuter line users thinks has performed very well but the user's expectations level is not too high.

The question items in Quadrant D are:

a) Item no 9: ease of reaching station location.

b) Item no 18: the ability of officers in carrying out their work

c) Item no 20: courtesy officer in providing services \& information.

d) Item no 24: availability of officers to appreciate and serve and prioritize customer needs.

e) Item no 25: commuter line train attempts to meet passenger needs. By looking at the statements in Quadrant D, it can be concluded that the performance on the items should not be upgraded. However, maintenance is needed. According to the users of the commuter line, the service is not very important because based on the data, the expectation rate is low. PT Kereta Commuter line needs to focus more on increasing the items that are important for the users since the performance is still low as Quadrant A.

There are two items which level of expectation is right on the $\mathrm{Y}$ axis line are:

a) Item no 21: ability of officers in keeping the passengers comfortability in train or at the station

b) Item no 5: Information sign and a complete service in every carriages

Based on the data in cartesius diagram, item no 5 and item no 21, according to commuter line train, have average expectations and its performance. The value has reached more than 3.51 . 


\section{Conclusion}

Based on the discussion about customers' satisfaction and quality of commuter line train service, it can be concluded as follows.

Based on the important performance analysis method, the expectation of commuter line passengers has not been fulfilled with the performance which is given by PT Kereta Commuter line. This can be proven from the overall level of conformity between performance and user expectations below 100\% indicating that the performance of PT Kereta Commuter Line has not been in line with users' expectations.

The analysis of Cartesian diagram shows that the question items must be increased are those in quadrant $\mathrm{A}$ and quadrant $\mathrm{C}$, they are: Item no 3, Item no 10, Item no 4. Item no 8 , Item no 7 , Item no 11 , Item no 14 , Item no 15 ,Item no 16,Item no 17, Item no 19.

Although the items in Quadrant C are not expected by Commuter Line Commuters, but low performance levels make them deserving to be prioritized for improvement. So base on our research PT KAI Commuter Line must increasing thier quality service level and give special attention for service item in quadran $\mathrm{A}$ and quadran $\mathrm{C}$ to fulfill and customer expectation.

$\bar{Y}$ (Expectation)

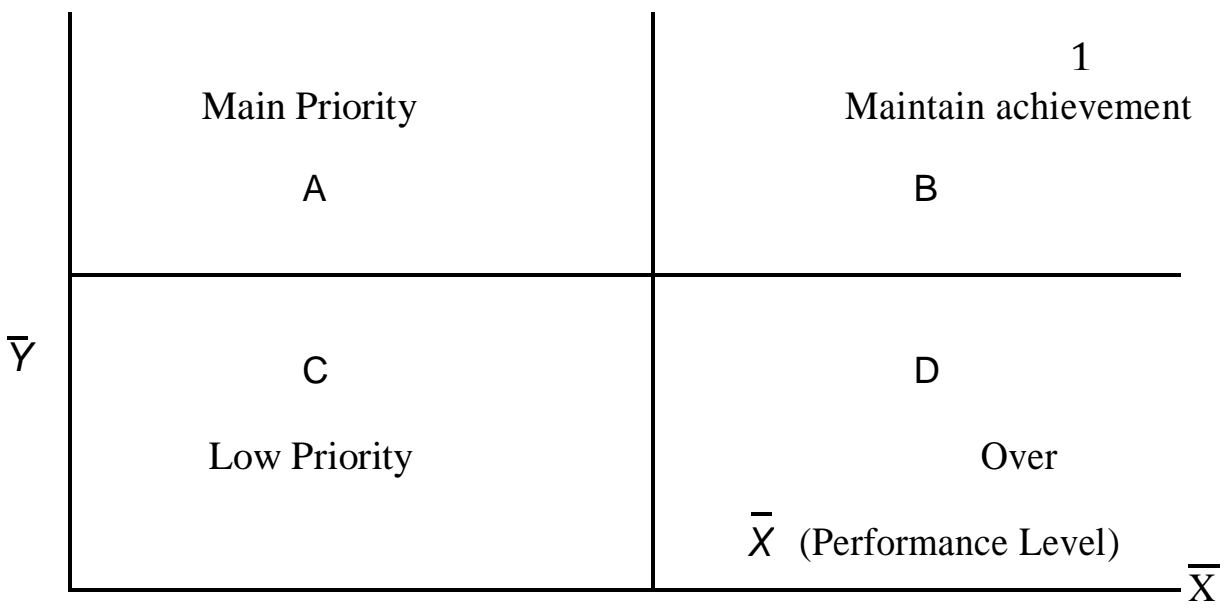

Figure 1. Cartesian Diagram 


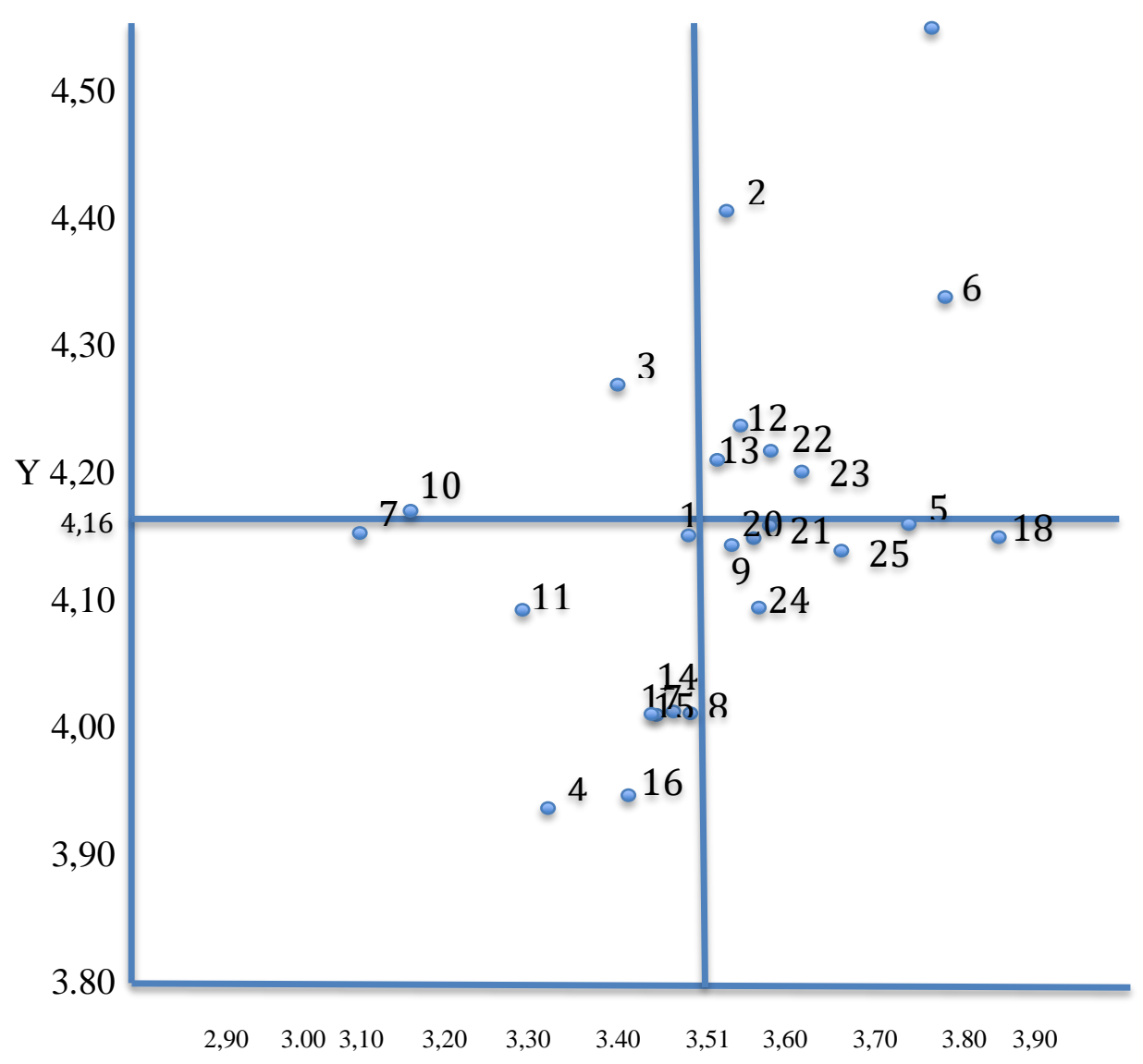

Figure 2. Cartesian Diagram

\section{References}

Kadarisman, M. (2016). Kebijakan Manajemen Transportasi Darat dan Dampaknya Terhadap Perekonomian Masyarakat di Kota Depok, 3(1).

Maesarini, I. W. dan R. R. F. (2013). Analisis Tingkat Kepuasan Pelanggan KRL Sistem Commuterline (Studi Kasus Pada PT. Kereta Api Commuter Jabodetabek), X No.1.

Simarmata, J. (2017). Building customer retention in on-line transportation, (July). https://doi.org/10.17512/pjms.2017.15.2.21

Supranto, J. (2011). Pengukuran Tingkat Kepuasan Pelanggan, Untuk Menaikkan Pangsa Pasar (p. 241). Jakarta: Rineka Cipta.

Thamrin, M. (2016). KUALITAS PELAYANAN JASA KEAGENAN

KAPAL DAN KOMUNIKASI INTERPERSONAL PADA SERVICES QUALITY OF SHIP AGENCY SERVICES AND INTERPERSONAL COMMUNICATION IN SHIPPING COMPANIES, 3(2), 217-225.

Wibowo, A. S. (2013). Analisis Kepuasan Konsumen Terhadap Kualitas Pelayanan Krl Commuter Line Bogor-Jakarta. 


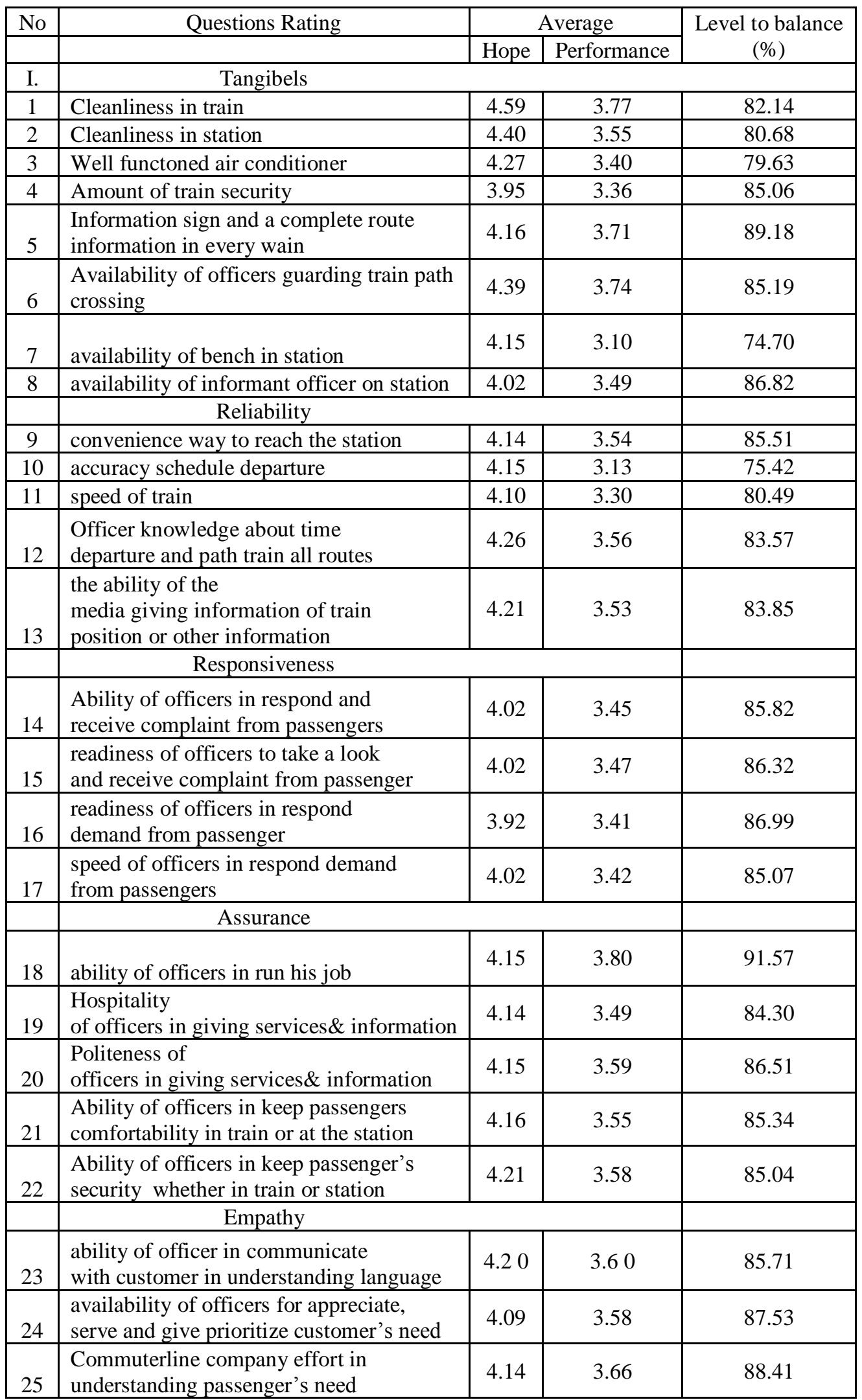

